\title{
Decreased expression of Insulin-like growth factor binding protein 3 and its death receptor in association with poor prognosis of the patients with gastric cancer
}

\section{Amir Ansari}

Isfahan University of Medical Sciences

Ali Gheysarzadeh ( $\sim$ Gheysarzad@gmail.com )

Ilam University of Medical Sciences

Hadi Bakhtiari

Isfahan University of Medical Sciences

Amirnader Emami Razavi

Tehran University of Medical Sciences

Akram Siavoshi

Ahvaz Jondishapour University of Medical Sciences Abadan Faculty of Nursing and Midwifery Abadan

Mohammad Reza Mofid

Isfahan University of Medical Sciences

\section{Research}

Keywords: IGFBP-3, IGFBP-3R, gastric cancer, prognostic factor

Posted Date: February 17th, 2020

DOI: https://doi.org/10.21203/rs.2.23614/v1

License: (c) (i) This work is licensed under a Creative Commons Attribution 4.0 International License.

Read Full License 


\section{Abstract}

Background: Gastric cancer (GC) as one of the most common cancers, serves as the third cause of cancer-related death. Insulin-like growth factor binding protein 3 (IGFBP-3) and its novel death receptor (IGFBP-3R) has been shown to have an anti-tumor effect however their prognostic values have not been elucidated yet.

Methods: IGFBP-3 and IGFBP-3R expression were evaluated with quantitative real-time polymerase chain reaction and western blotting in patients with $\mathrm{GC}(\mathrm{N}=68)$. The relationship between prognostic factors such as tumor stage, tumor grade, tumor size, metastases, and Overall Survival (OS) with IGFBP-3/IGFBP$3 \mathrm{R}$ expression was also assessed.

Results: IGFBP-3 and its death receptor expression were determined as dialectic evidence. In the experimental procedure, IGFBP-3 and IGFBP-3R expression were reduced in tumor tissues significantly. We found that there was an association between the reduction of IGFBP-3 with lymph node metastasis and TMN staging $(P<0.001)$. In addition, IGFBP-3R expression was associated with tumor size $(P=0.004$ ), lymph node metastasis $(P<0.001)$, differentiation $(P=0.002)$ and TNM classification $(P=0.005)$. Interestingly, we presented that the downregulation of IGFBP-3R was stage-dependent. In OS analysis, we offered that low levels of IGFBP-3R mRNA expression were unfavorable with survival rate $(P=0.002)$. IGFBP-3 regardless of its relationship with some prognostic parameters, there was no significant relationship between IGFBP-3 and OS.

Conclusion: The findings of this study showed that IGFBP-3R has the potential to be a new prognostic biomarker of GC. But despite some benefit of IGFBP-3, it cannot be accepted as a prognostic biomarker. However, this finding must be improved and confirmed by future studies.

\section{Introduction}

Gastric cancer (GC) occupies the fifth most common and the third position for the leading cause of cancer-related deaths worldwide. The 5-year survivals in gastric cancer patients with adjuvant treatment can extend to be less than $23 \%$, making this type of cancer as one of the most lethal cancers $(1,2)$. GC treatment is more likely to be a combination of chemotherapy, radiation and surgery. Mortality of GC was decreased during the past decades, resulting from surgical achievements and adjuvant therapy. GC identification usually takes place just after its symptoms represented in its advanced stage (3). Due to the poor prognosis, understanding of the molecular mechanism involved in cancer progression can improve prognosis and prevent metastasis to other organs $(4,5)$.

Insulin-like growth factor-binding protein 3 (IGFBP-3) is known as a multi-functional protein which can bind to $80 \%$ of IGF-I and II with high affinity to modulate their bioactivity (6). This conserved protein enables to form a ternary complex with acid-labile subunit (ALS) increasing IGF-I/II half-life (7). The main function of IGFBP-3 was identified in a wide variety of cancers. 
IGFBP-3 has also been shown to induce apoptosis in an IGF-independent manner (8). For the first time, Oh Y demonstrated that IGFBP-3 can bind to the specific receptor in IGF-independent action (9). IGFBP-3 receptor (IGFBP-3R), a single span membrane protein, was identified as a novel cell death receptor by Ingerman. In addition, it was also demonstrated that IGFBP-3R which is wildly expressed in most of the tissues and encoded by TMEM 219 (Transmembrane protein 219) gene, contains 240 amino acids residues in length and interacts with IGFBP-3 in the cellular membrane (10). Recently it has been shown that impairing of IGFBP-3/IGFBP-3R axis occurs in many of malignancies. IGFBP-3 expression appears to be suppressed in many cancers, due to some epigenetic alteration like hypermethylation (11). In addition, IGFBP-3R expression is significantly reduced in invasive breast ductal carcinoma, pancreatic ductal adenocarcinoma, and prostate tumor cells $(10,12)$. Thus, investigation of IGFBP-3/IGFBP-3R axis may provide prognostic and therapeutic value for primary diagnosis/staging and gastric cancer treatment.

In the present study, IGFBP-3 and IGFBP-3R expression were evaluated using qRT-PCR and western blotting in GC tumor tissues in compared with their normal adjacent tissues to serve as the potential prognostic marker in GC. The association of mentioned protein expression with clinicopathological features was evaluated as well.

\section{Materials And Methods}

RNA sequencing data Analysis

In order to determine the level of expression of TMEM 219 (IGFBP-3R) and IGFBP-3, four RNA-Seq datasets (SRP135952, SRP133891, SRP012016, SRP073446) from the Sequence Read Archive (SRA) (www.ncbi.nlm.nih.gov/geo) and three datasets (GSE122401, GSE63288, GSE106338) from Gene Expression Omnibus (GEO), all related to patients with GC, were downloaded. The datasets from SRA was analyzed to process raw data by using Ubunto (18.04 LTS) and then was statistically interpreted to determine Differential Expression Genes (DEGs) by using software R (version 3.5.1). According to the lowquality sequence, the sequences were trimmed using Trimmomatic to remove reads with quality less than Q20 and adapter (first 15 bp of reads) (13). High-quality data (All clean reads) were mapped to Homo sapiens genome reference (UCSC version hg38) using HISAT2 (14) with mapping efficiencies around $97 \%$, the counting was performed using HTSeq followed by differential expression analysis on each normal and tumor gastric replicates (15). In the end, normalization of the count was performed using R/Bioconductor limma package. All Geo dataset were already normalized and just the analysis of differential expression was performed using limma to determine DEGs (16).

Clinical Tissue Samples

All of 68 pair gastric cancer samples collected from gastric cancer surgical specimens, between April 2014 until September 2016 from Iran National Tumor Bank (INTB, Tehran, Iran). Each patient was written informed consent form, procedures according with the ethical standards of the institutional and/or national research committee of the 2013 Helsinki declaration and investigation has been approved with ethical committee members of the Medical University of Isfahan (Ethic number: 396386). Specimens 
without prior radiotherapy, chemotherapy or any treatments were enrolled in the study. All of the samples were evaluated by two independent pathologists blinded to the clinical features. Samples characterized according to the American Cancer Society and tumor-node-metastasis (TNM) classification system guidelines (17). Normal samples were removed from the marginal zone of cancer tissue and used as a control. Immediately, all samples were snap-frozen in liquid nitrogen until the relevant assays were performed. The clinicopathological features of samples were summarized in Table 1. 
Table 1

Association of clinicopathological features with IGFBP-3 and IGFB-3R mRNA relative expression in 68 patients with gastric cancer. ${ }^{*}(P<0.05)$ indicates that the differences have statistical significance.

*Pearson chi-square tests.

\begin{tabular}{|c|c|c|c|c|c|c|c|}
\hline \multirow[t]{2}{*}{ Parameters } & \multirow[t]{2}{*}{$\begin{array}{l}\text { Number of } \\
\text { patients }\end{array}$} & \multicolumn{2}{|c|}{$\begin{array}{l}\text { IGFBP-3 }{ }^{1} \text { mRNA } \\
\text { expression }\end{array}$} & \multirow{2}{*}{$\begin{array}{l}P \\
\text { value } \\
2\end{array}$} & \multicolumn{2}{|c|}{$\begin{array}{l}\text { IGFBP-3R }{ }^{3} \text { mRNA } \\
\text { expression }\end{array}$} & \multirow{2}{*}{$\begin{array}{l}P \\
\text { value } \\
2\end{array}$} \\
\hline & & Low & High & & Low & High & \\
\hline Age & & & & 0.250 & & & 0.163 \\
\hline$<61$ & $28(41.2 \%)$ & 12 & 16 & & 12 & 16 & \\
\hline$\geq 61$ & $40(58.2 \%)$ & 28 & 12 & & 24 & 16 & \\
\hline Sex & & & & 0.536 & & & 0.254 \\
\hline Male & $54(79.4 \%)$ & 32 & 22 & & 30 & 24 & \\
\hline Female & $14(20.6 \%)$ & 8 & 6 & & 6 & 8 & \\
\hline Tumor size & & & & 0.146 & & & 0.004 \\
\hline$<6$ & 34 (50\%) & 14 & 20 & & 12 & 22 & \\
\hline$\geq 6$ & $34(50 \%)$ & 26 & 8 & & 24 & 10 & \\
\hline $\begin{array}{l}\text { Lymph node } \\
\text { invasion }\end{array}$ & & & & $\begin{array}{l}< \\
0.001\end{array}$ & & & $\begin{array}{l}< \\
0.001\end{array}$ \\
\hline Positive & $50(73.5 \%)$ & 34 & 16 & & 32 & 18 & \\
\hline Negative & $18(26.5 \%)$ & 6 & 12 & & 4 & 14 & \\
\hline Differentiation & & & & 0.186 & & & 0.002 \\
\hline Poor & $18(26.5 \%)$ & 8 & 10 & & 0 & 18 & \\
\hline Moderate & 40 (58.8\%) & 26 & 14 & & 30 & 10 & \\
\hline High & $10(14.7 \%)$ & 6 & 4 & & 6 & 4 & \\
\hline TMN stage & & & & $\begin{array}{l}< \\
0.001\end{array}$ & & & 0.005 \\
\hline $\mid \mathrm{B}+\mathrm{II}$ & $26(38.2 \%)$ & 10 & 16 & & 10 & 16 & \\
\hline
\end{tabular}

${ }^{1}$ Insulin-like growth factor binding protein-3

2 P-value was calculated from one-way ANOVA with Tukey post hoc and independent T-test

${ }^{3}$ Insulin-like growth factor binding protein-3 receptor 


\begin{tabular}{|c|c|c|c|c|c|c|c|}
\hline \multirow[t]{2}{*}{ Parameters } & \multirow[t]{2}{*}{$\begin{array}{l}\text { Number of } \\
\text { patients }\end{array}$} & \multicolumn{2}{|c|}{$\begin{array}{l}\text { IGFBP- } 3^{1} \text { mRNA } \\
\text { expression }\end{array}$} & \multirow{2}{*}{$\begin{array}{l}P \\
\text { value } \\
2\end{array}$} & \multicolumn{2}{|c|}{$\begin{array}{l}\text { IGFBP-3R }{ }^{3} \text { mRNA } \\
\text { expression }\end{array}$} & \multirow{2}{*}{$\begin{array}{l}P \\
\text { value } \\
2\end{array}$} \\
\hline & & Low & High & & Low & High & \\
\hline IIIA & $18(26.5 \%)$ & 10 & 8 & & 8 & 10 & \\
\hline IIIB + IV & $24(35.5 \%)$ & 20 & 4 & & 18 & 6 & \\
\hline \multicolumn{8}{|c|}{${ }^{1}$ Insulin-like growth factor binding protein-3 } \\
\hline \multicolumn{8}{|c|}{${ }^{2}$ P-value was calculated from one-way ANOVA with Tukey post hoc and independent T-test } \\
\hline \multicolumn{8}{|c|}{${ }^{3}$ Insulin-like growth factor binding protein-3 receptor } \\
\hline
\end{tabular}

Chemicals, Reagents, And Antibodies

RNA extraction reagent (RNX ${ }^{\mathrm{TM}}$-plus) and DNase I was provided from Cinnagen (Cinnagen, Tehran, Iran). cDNA synthesis kit and the enhanced chemiluminescent detection system (ECL) were purchased from Takara (Tokyo, Japan). All primers and qPCR Master Mixmix SYBR Green (high ROX) obtained from Ampliqun (Herlev, Denmark). Primary sheep polyclonal anti-IGFBP-3R (AF7556-SP) and secondary donkey anti-sheep IgG horseradish peroxidase (HRP)-conjugated antibody (HAF016) were purchased from R\&D (Minneapolis, USA). Mouse monoclonal antiß-actin and anti-IGFBP-3, secondary mouse anti-goat IgG HRP-conjugated was obtained from Santa Cruz Biotechnology (Santa Cruz, CA, USA). Electrophoresis reagents and materials provided by Bio-Rad (Hercules, CA, USA). Other chemical and reagent obtained from Sigma Aldrich (St. Louis, MO, USA).

\section{Quantitative RT-PCR}

Before RNA extraction, tissues were washed with ice-cold phosphate buffer saline (PBS). Total RNA was extracted from all tissues by using $\mathrm{RNX}^{\mathrm{TM}}$-plus according to the manufacturer's protocol. Frozen tissues (20-30 mg) homogenized by the bead-milling method in $1 \mathrm{ml}$ of $\mathrm{RNX}^{\mathrm{TM}}$-plus reagent as described previously(18). Subsequently, for the elimination of genomic DNA, the suspension was treated with DNase I. RNA concentration was then determined by ultraviolet spectrophotometer (BioTek,Winooski, VT, USA) using A260/A280 ratio and then the RNA samples were stored at $-80^{\circ} \mathrm{C}$.

Total RNA $(2 \mu \mathrm{g})$ was used for cDNA synthesize according to the kit's protocol as following: reaction mixture up to $10 \mu \mathrm{l}$ and without a hot start, 1 cycle at $37^{\circ} \mathrm{C}$ for $15 \mathrm{~min}$ for reverse transcription and $94^{\circ} \mathrm{C}$ for $30 \mathrm{~s}$ for enzyme inactivation. Real-time PCR was performed utilizing an ABI Prism 7500 sequence detection system (Applied Biosystems, Foster City, CA, USA). The sequences of primers were used as follow: IGFBP-3 forward: 5'-GGTGTCTGATCCCAAGTTCC-3', IGFBP-3 reverse: 5'-

ACCATATTCTGTCTCCCGCT-3'; IGFBP-3R forward: 5'-TGACCACCTTGAACTTCG-3', IGFBP-3R reverse: 5'- 
GCAGAAGATCCTTTCAATC-3'; GAPDH forward: 5'-CAGCCTCAAGATCATCAGC-3', GAPDH reverse: 5'GGCAGTGATGGCATGGACT-3'.

The final volume of the reaction mixture $(10 \mu \mathrm{l})$ contained $1 \mathrm{ng}$ of cDNA template, $200 \mathrm{nM}$ each of sense and antisense primers and $5 \mu \mathrm{l}$ of $2 X$ SYBR Green PCR. The reaction conditions were as follows: after an initial hot start $\left(95^{\circ} \mathrm{C}\right)$ for $10 \mathrm{~min}$, amplification was performed for 40 cycles containing denaturation for $10 \mathrm{~s}$ at $94^{\circ} \mathrm{C}$, annealing for $30 \mathrm{~s}$ at $50^{\circ} \mathrm{C}$, and extension for $40 \mathrm{~s}$ at $72 \mathrm{C}$. The amplification kinetics was recorded as sigmoid progress curves for which fluorescence was interoperated against the number of amplification cycles. The threshold cycle number was used to define the initial amount of each template. Fluorescence readings were carried out in every amplification cycle, using StepOnePlus (Applied Biosystems, Foster City, CA, USA). All measurements were performed in triplicate. The sizes of the amplified fragments were confirmed by agarose gel $2 \%$ electrophoresis.

The relative expression was normalized with the GAPDH as an internal control. Then fold change calculated according to the $2^{-\Delta \Delta \mathrm{Ct}}$ method: $\Delta \Delta \mathrm{Ct}=\left[\mathrm{Ct}_{\text {gene of interest }}{ }^{-\mathrm{Ct}}{ }_{\mathrm{GAPDH}}\right]_{\text {(cancerous tissues) }}{ }^{-[\mathrm{Ct}}$ gene of interest $-{ }^{-} t_{\text {GAPDH }}$ (normal-adjacent tissue) similar with our previous study

Western Blotting

IGFBP-3 and IGFBP-3R protein expression were evaluated with western blotting as described previously(12). Summary, 100 milligrams of the fresh frozen tissues washed three times with ice-cold PBS. The tissues were homogenized by the bead-milling method in $1 \mathrm{ml}$ ice-cold RIPA buffer ( $50 \mathrm{mM}$ Tris$\mathrm{Cl}$ [pH 7.4], $150 \mathrm{mM} \mathrm{NaCl}, 15 \mathrm{mM} \mathrm{Na}_{4} \mathrm{P}_{2} \mathrm{O}_{7}, 20 \mathrm{mM} \mathrm{NaF}, 1 \mathrm{mM}$ EDTA, 1 mM PMSF, 6 mM EGTA, $100 \mathrm{mM}$ glycerol 3-phosphate, $1 \%$ NP-40 [NP-4] and $1 \%$ Sodium Deoxycholic acid supplemented with $0.5 \%$ freshly protease and phosphatase inhibitors cocktail (Melford). The lysates were harvested with centrifugation $(14,000 \mathrm{rpm})$ at $4^{\circ} \mathrm{C}$ for $25 \mathrm{~min}$ and the supernatant stored in $-80^{\circ} \mathrm{C}$.

The protein concentrations were measured with the Bradford protein assay. All protein samples were incubated with Laemmli buffer at $100^{\circ} \mathrm{C}$ for $5 \mathrm{~min}$, an equal amount $(40 \mu \mathrm{g})$ of total proteins were separated by electrophoresis in a $12 \%$ sodium dodecyl sulfate-polyacrylamide gel electrophoresis (SDSPAGE, Ready Gel, Bio-Rad). Following, transferred onto a polyvinylidene fluoride membrane (PVDF, Amersham Pharmacia Biotech), membranes were blocked with Tris-buffered saline, containing 5\% nonfat dried milk and $0.1 \%$ Tween (TBS-T) for $2 \mathrm{~h}$ in room temperature. After 3 time wash with TBS-T, membranes incubated overnight with primary antibodies at $4{ }^{\circ} \mathrm{C}(1: 1000$ in TBS-T, $0.1 \%$ Tween 20 and $0.1 \% \mathrm{BSA}$ ). After washing three times with TBS-T for $5 \mathrm{~min}$, the membranes were incubated in secondary antibodies (1:2500 in TBS-T, 0.1\% Tween 20 and 0.1\% BSA) horseradish peroxidase (HRP). After three times washing with TBS-T protein bands were detected with ECL reagent. All bands were normalized by $\beta$ actin as the internal control. The relative intensity of all bands was quantified by densitometry, using the Image $\mathrm{J}$ software ( $\mathrm{NIH}$, Bethesda, MA, USA).

Statistical analysis 
Datasets from SRA database was analyzed to process raw data using Ubuntu (18.04 LTS) and then, to statistical calculation and interpretation of Differential Expression Genes (DEGs) used Statistical software R (version 3.5.1, https://www.r-project.org/). The comparison of RNA and protein relative expression levels between the normal and the tumor tissues assessed with paired Student's t-test. The One-way ANOVA (with Tukey posthoc) and independent sample T-test were used to evaluate the relationship between clinicopathological parameters and IGFBP-3/IGFBP-3R expression. The overall survival rates were calculated by the Kaplan-Meier method and differences in survival rates for between subgroup patients (high and low expression) were analyzed with the log-rank test. All experiments performed as triplicate and data were presented as mean \pm SEM. Statistical significance was determined at the level of $P<0.05$. All data were analyzed with SPSS 22 (SPSS, Chicago, IL, USA).

\section{Result}

\section{Patients}

This study contains 54 males and 14 females. Median ages of patients with GC were $62 \pm 10$ years (ranged 33-76 years). The tumor size was classified into two groups based on the mean (6 centimeters), there are three grades for tumors categorized to poor, moderate and well differentiation (Grade 3, 2 and 1, respectively) the stage was classified in IB + II, IIIA, and IIIB + IV. All clinicopathological features of patients were summarized in Table 1.

Identifying the IGFBP-3 and its death receptor gene expression in databases

After filtering the raw count of gene expression matrix that is lowly expressed (30\% of genes in each dataset had zero counts across all samples), we checked the distribution of the raw read counts after log2 transformation using boxplot (Fig. 1a). Read count normalization of CPM (counts per million) was performed on gene expressing matrix with limma (Fig. 1b) and after normalization, limma was also used to screen the DEGs between gastric tumor and normal groups with a special threshold (padj $<0.05, \log 2$ FC <-1| $\log 2$ FC > 1) in all datasets. The significance level of the expression of TMEM 219 and IGFBP-3 in each dataset is shown in the Table 2. In most datasets, IGFBP-3 was down-regulated in tumor tissue and in two datasets reduction in the expression was significant. According to the results, TMEM 219 showed controversial expression changes in tumor tissues and paired normal tissues so needed to be further analyzed using other methods like qRT-PCR and western blotting. 
Table 2

Gene expression level of IGFBP-3 and TMEM 219 (IGFBP-3R) in different RNA-seq datasets of gastric cancer (normal vs tumor) with a special threshold (padj $<0.05$, log2 FC $<-1 \mid \log 2 \mathrm{FC}>1$ ). These two genes were differentially expressed In GSE122401, GSE63288 and GSE106338. The level of gene expression of

these two gens in four data sets (SRP135952, SRP133891, SRP073446, SRP012016) was low but Significance level of genes expression was not impressive.

\begin{tabular}{|c|c|c|c|c|c|}
\hline Dataset & $\begin{array}{l}\text { Number of } \\
\text { samples } \\
\text { (tumor/normal) }\end{array}$ & $\begin{array}{l}\text { Gene } \\
\text { symbol }\end{array}$ & $\log 2 \mathrm{FC}$ & padj & $\begin{array}{l}\text { Gene } \\
\text { regulation } \\
\text { (padj < } \\
0.05 \text {, log2 } \\
F C<-1 \mid \\
\log 2 F C> \\
1)\end{array}$ \\
\hline GSE122401 & $160(80 / 80)$ & TMEM219 & 5.929084744 & 4.30E-06 & $\begin{array}{l}\text { Up- } \\
\text { regulated }\end{array}$ \\
\hline \multirow[t]{2}{*}{ GSE63288 } & $44(22 / 22)$ & IGFBP-3 & -4.029501 & 0.000230573 & $\begin{array}{l}\text { Down- } \\
\text { regulated }\end{array}$ \\
\hline & & TMEM219 & 0.038779382 & 0.886275834 & - \\
\hline \multirow[t]{2}{*}{ GSE106338 } & $6(10 / 5)$ & IGFBP-3 & -0.644756605 & 0.015192113 & $\begin{array}{l}\text { Down- } \\
\text { regulated }\end{array}$ \\
\hline & & TMEM219 & 0.304485256 & 0.040597407 & - \\
\hline \multirow[t]{2}{*}{ SRP133891 } & $6(3 / 3)$ & IGFBP-3 & 6.390124314 & 2.69E-13 & $\begin{array}{l}\text { UP- } \\
\text { regulated }\end{array}$ \\
\hline & & TMEM219 & -0.024690081 & 0.999295723 & - \\
\hline \multirow[t]{2}{*}{ SRP073446 } & $6(2 / 3)$ & IGFBP-3 & -1.214712018 & 0.477523199 & - \\
\hline & & TMEM219 & 1.709564312 & 0.034660516 & - \\
\hline \multirow[t]{2}{*}{ SRP135952 } & $12(6 / 6)$ & IGFBP-3 & 0.064407026 & 0.961976295 & - \\
\hline & & IGFBP-3 & -2.08302277903425 & 0.99993861 & - \\
\hline \multirow[t]{2}{*}{ SRP012016 } & $6(3 / 3)$ & TMEM219 & 0.358402202 & 0.99993861 & - \\
\hline & & IGFBP-3 & -1.751039396 & 0.128781382 & \\
\hline
\end{tabular}

IGFBP-3 expression reduced in GC tumor tissue in comparison with normal adjacent tissue

We measured the IGFBP-3expression in 68 paired GC tissue and normal marginal zone. In real-time qRTPCR, the results indicated that the mRNA relative expression of IGFBP-3 markedly reduced in cancerous tissue in comparison with normal adjacent tissue (Fold change: $0.47 \pm 0.04$, Fig. $2 a$ and $P<0.001$ ). 
Analyzing based on different TNM stage and fold changes indicated that overall IGFBP-3 expression decreased in all stages (Fig. 2b). Also, relative protein expression of IGFBP-3 evaluated with western blotting by using $\beta$-actin as an internal control (Fig. 3a). The results indicating that the protein expression was reduced compared with paired normal tissue (Fold change: $0.85 \pm 0.13$, Fig. $3 b$ and $P<0.001$ ). Then, the pattern of protein expression for IGFBP-3 was analyzed. In according to TNM staging, IGFBP-3 protein reduction in stage IB + II stage was not significant, but in IIIA $(0.62 \pm 0.11, P=0.018)$ and IIIB + IV stages $(0.45 \pm 0.05 \mathrm{P}<0.001)$ were statistically significant (Fig. 3c).

IGFBP-3R expression reduced significantly in GC tumor tissue compared with normal adjacent tissue Our findings indicated that mRNA relative expression of IGFBP-3R was markedly reduced in GC tumor tissue in comparison to paired normal tissue (Fold change: $0.49 \pm 0.05$, Fig. $4 a$ and $P<0.001$ ). TNM stage analysis revealed that IGFBP-3R mRNA expression were significantly reduce stage dependent in IB + II $(0.69 \pm 0.12, P=0.003)$, IIIA $(0.56 \pm 0.11, P<0.001)$ and IIIB + IV $(0.22 \pm 0.06, P<0.001)$ stage (Fig. $4 b)$. In western blotting analysis (Fig. 5a), IGFBP-3R protein expression normalized by $\beta$ - actin, was significantly reduced in GC tumor tissue (Fold change: $0.53 \pm 0.02$, Fig. $5 \mathrm{~b}$ and $P<0.001$ ). In addition, analysis of IGFBP-3R protein expression pattern indicated that it depends on stages IB $+I I(0.77 \pm 0.01, P<0.001)$ and IIIA $(0.37 \pm 0.02, P<0.001)$. But decreasing expression of this protein in not significant in IIIB + IV stage (Fig. 5c).

Association between IGFBP-3 and IGFBP-3R expression with clinical-pathological parameters in patients with gastric cancer

The relationship between IGFBP-3 and IGFBP-3R relative expression with clinicopathological variables were analyzed by One-way ANOVA (with Tukey posthoc) and independent sample T-test and listed in Table 1. The analysis revealed that IGFBP-3 expression associated with lymph node invasion and TNM stage $(P<0.001)$ strongly. Moreover, analyzing IGFBP-3R expression revealed that the low-level expression associated with tumor size $(P=0.004)$, lymph node invasion $(P<0.001)$, differentiation $(P=$ $0.002)$ and TNM stage $(P=0.005)$. However there was no relationship between IGFBP-3 and IGFBP-3R expression with other parameters including age and sex.

Correlation of the IGFBP-3 and its death receptor expression level with overall survival

The association of the Overall Survival (OS) of the GC patients ( $N=68)$ with IGFBP-3 and its death receptor expression were evaluated. The analysis was performed as Kaplan-Meier with the log-rank test. The low or high expression level was interpreted according to the mean. Patient with high levels of IGFBP3R mRNA expression $(\mathrm{N}=32)$ had better survival in comparison with low levels of mRNA expression $(\mathrm{N}=$ 36) (survival time: $24 \pm 1.31$ months versus $18 \pm 6.33$ months, $P=0.002$, Fig. 6a). However, survival rate analysis based on IGFBP-3 indicated no significant difference between the low and high expression of IGFBP-3 ( $P=0.075$, Fig. $6 b)$.

\section{Discussion}


Proteomics study around the protein biomarkers has indicated that some proteins might serve as the potential prognostic biomarker (19-21). It has been revealed that IGFBPs, specifically IGFBP-3, could be considered as a potential prognostic biomarker (22-24). In the present study, we provide a new information around IGFBP-3/IGFBP-3R axis gene expression via RNA-seq analysis, mRNA and protein analysis as well as their correlations with clinicopathological features. First, we considered some available raw and processed RNA-seq datasets related to GC tumor and adjacent normal tissues. Then, we assessed the differential expression level of IGFBP-3 and its death receptor (TMEM 219). Our analysis of datasets revealed that IGFBP-3 is down-regulated while, the results for TMEM 219 expresion were controversial (Fig. 1 and Table 2). Despite having a wide dynamic range of detection and negligible background signal in comparison with other known detection methods (25), it is believed that RNA-Seq data of differentially expressed genes (DEGs) might because of its variation and bias. Therefore proper normalization methods and validation with an accurate gold standard like qRT-PCR were also definitely needed $(26,27)$. This fact interested us to further consider the differential expression using more exacting conformational methods like qRT-PCR and western blotting analysis.

In the present study, we also showed that IGFBP-3 and IGFBP-3R expression is reduced in mRNA level (Fig. 2a and Fig. 4a). In line with our findings, it has been reported that IGFBP-3 promoter methylation, and its reduction of expression, in early-stages of GC is critical in predicting survival (28). Zhang et al also revealed that IGFBP-3 has a protective effect the development of GC and its down regulation affect the prognosis (29).

The exact mechanism highlighting IGFBP-3 and its receptor roles in GC progression are partially understood $(7,8,12,30)$. In this regard, IGFBP-3 has been extensively considered as a p53-inducible gene that insatiate apoptosis in cells and tumor (31). Baxter et al also declared that IGFBP-3 is known as a novel ligand mediating apoptosis through nucleus internalization $(32,33)$. Moreover, previous in silico study revealed that IGFBP-3 phosphorylation on ser111 which occurred in apoptosis induction, make a repulsive effect with IGF-I faciliting IGFBP-3 interaction with IGFBP-3R in outer membrane (34). Furthermore, Xue and collagus also indicated that IGFBP-3 can suppres some invasion factor like urokinase-type plasminogen activator (UPA) and MMP-14 (35). Harada and colleagues also showed that IGFBP-3 can induce apoptosis via IGFBP-3R in lung cancer (36). Similarly, IGFBP-3R interacts with nuclear factor kappa light chain enhancer of activated B cells (NF-KB) pathway and suppresses tumor growth (37, 38). It was demonstrated that in cancer status, the increasing level of intra or extracellular proteases like Matrix metallopeptidases (MMPs) and serine proteases may affect IGFBP-3 level. Kallikrein 11 in breast cancer can degrade IGFBP-3 and increase the bioactivity of IGFs (39). This fact is supported with our IGFBP-3 western blotting analysis as well (Fig. 3b and 3c).

In this study, we also showed that IGFBP-3 was markedly reduced in mRNA and protein level (Fig. 2a and Fig. 4a). This decline correlated with the stage and grade progressions (Table 1, Fig. 2b and 3c). To support IGFBP-3 roles in a higher stage of cancer, a meta-analysis indicated that the reduced IGFBP-3 expression is associated to higher cancer risk, lower survival rate, and more advanced tumor stages of esophageal cancer (46). Similarly, ovarian endometrioid carcinoma (EC), glioblastoma, colorectal cancer 
and gastric adenocarcinoma have been reported to associate with low IGFBP-3 expression $(22,40-43)$. This fact can support our clinicopathological features analysis (Table 1). In line with the current study, the low IGFBP-3 expression has been reported to correlate clinically with higher invasion rate in different cancers including pancreatic ductal adenocarcinoma, ovarian carcinoma, prostate cancer, and Non-small cell lung cancer (NSCLC) $(12,40,44,45)$.

Similarly, a more recent study uncovered that low expression of IGFBP3 is linked to certain clinicopathological features and the poor overall survival of patients with hepatocellular carcinoma and pancreatic cancer $(12,47)$. However, in our study, IGFBP-3 expression was not correlated with survival, but IGFBP-3R expression was associated with poor survival (Fig. 6a and b).

\section{Conclusion}

Taken together the current study tried to highlight IGFBP-3/IGFBP-3R axis in GC and representing new information about IGFBP-3R. We demonstrated that a decrease in IGFBP-3 and IGFBP-3R expression is associated with clinicopathological features. Additionally, we demonstrated that IGFBP-3R relative expression was significantly associated with low survival time and poor prognosis in patients with GC. IGFBP-3 and its death receptor expression pattern indicated that they could be recruited as a potential biomarker for TNM staging and prognosis detection. However further investigations are needed for more validation.

\section{Abbreviations}

Gastric cancer (GC)

Insulin-like growth factor binding protein 3 (IGFBP-3)

Insulin-like growth factor binding protein 3 receptor (IGFBP-3R)

Overall Survival (OS)

Lymph Node Metastasis (TMN)

Acid-labile subunit (ALS)

Transmembrane protein 219 (TMEM 219)

Sequence Read Archive (SRA)

Gene Expression Omnibus (GEO)

Differential Expression Genes (DEGs)

Iran National Tumor Bank (INTB) 
Horseradish Peroxidase (HRP)

Phosphate Buffer Saline (PBS)

plasminogen activator (UPA)

Matrix metallopeptidases (MMPs)

Endometrioid carcinoma (EC)

Non-small cell lung cancer (NSCLC)

\section{Declarations}

\section{Ethics approval and consent to participate}

Human tissue experiments were reviewed and approved by the Isfahan University of Medical Sciences Consent for publication

Not applicable

\section{Availability of data and materials}

All data and materials are available on request to corresponding author

\section{Competing interests}

All authors declare that there is no conflict of interest.

\section{Funding}

This study was funded and supported by the Isfahan University of Medical Sciences (396386).

\section{Authors' contributions}

A.A and contributed in the conception of the work, conducting the study, writhing the draft.

A.Gh contributed in the conception of the work, approval of the final version of the manuscript, acquisition and analysis of data.

H.B contributed in the conception of the work or design of the work, acquisition and analysis of data and writhied the draft.

A.E.R contributed in the conception of the work or design of the work, approved the final version of the manuscript 
A.S contributed in the conception of the work or design of the work, acquisition and analysis of data and writhed the draft

M.R.M. supervied the study, contributed in the design of the work, acquisition and analysis of data revising the draft and approval of the final version of the manuscript

\section{Acknowledgement:}

This study was funded and supported by the Isfahan University of Medical Sciences (396386).

\section{References}

1. Chua YJ, Cunningham D. The UK NCRI MAGIC trial of perioperative chemotherapy in resectable gastric cancer: implications for clinical practice. Springer; 2007.

2. Siegel RL, Miller KD, Jemal A. Cancer statistics, 2016. CA: a cancer journal for clinicians. 2016;66(1):7-30.

3. Wagner AD, Syn NL, Moehler M, Grothe W, Yong WP, Tai BC, et al. Chemotherapy for advanced gastric cancer. Cochrane database of systematic reviews. 2017 (8).

4. Abbas M, Habib M, Naveed M, Karthik K, Dhama K, Shi M, et al. The relevance of gastric cancer biomarkers in prognosis and pre-and post-chemotherapy in clinical practice. Biomedicine \& Pharmacotherapy. 2017;95:1082-90.

5. Matsuoka T, Yashiro M. Biomarkers of gastric cancer: current topics and future perspective. World journal of gastroenterology. 2018;24(26):2818.

6. Ranke MB. Insulin-like growth factor binding-protein-3 (IGFBP-3). Best Practice \& Research Clinical Endocrinology \& Metabolism. 2015;29(5):701-11.

7. Baxter RC. IGF binding proteins in cancer: mechanistic and clinical insights. Nature Reviews Cancer. 2014;14(5):329.

8. ANSARI A, GHEYSARZADEH A, MOFID MR. The interaction of insulin-like growth factor binding protein 3 (IGFBP-3) in insulin-like growth factor (IGF)-independent system. 2017.

9. Kim H-S, Ingermann AR, Tsubaki J, Twigg SM, Walker GE, Oh Y. Insulin-like growth factor-binding protein 3 induces caspase-dependent apoptosis through a death receptor-mediated pathway in MCF7 human breast cancer cells. Cancer research. 2004;64(6):2229-37.

10. Ingermann AR, Yang Y-F, Han J, Mikami A, Garza AE, Mohanraj L, et al. Identification of a novel cell death receptor mediating IGFBP-3-induced anti-tumor effects in breast and prostate cancer. Journal of biological chemistry. 2010;285(39):30233-46.

11. Perks CM, Holly JM. Epigenetic regulation of insulin-like growth factor binding protein-3 (IGFBP-3) in cancer. Journal of cell communication and signaling. 2015;9(2):159-66.

12. Gheysarzadeh A, Bakhtiari H, Ansari A, Emami Razavi A, Emami MH, Mofid MR. The insulin-like growth factor binding protein-3 and its death receptor in pancreatic ductal adenocarcinoma poor 
prognosis. Journal of cellular physiology. 2019.

13. Bolger AM, Lohse M, Usadel B. Trimmomatic: a flexible trimmer for Illumina sequence data. Bioinformatics. 2014;30(15):2114-20.

14. Kim D, Langmead B, Salzberg SL. HISAT: a fast spliced aligner with low memory requirements. Nature methods. 2015;12(4):357.

15. Anders S, Pyl PT, Huber W. HTSeq-a Python framework to work with high-throughput sequencing data. Bioinformatics. 2015;31(2):166-9.

16. Ritchie ME, Phipson B, Wu D, Hu Y, Law CW, Shi W, et al. limma powers differential expression analyses for RNA-sequencing and microarray studies. Nucleic acids research. 2015;43(7):e47-e.

17. Sobin LH, Gospodarowicz MK, Wittekind C. TNM classification of malignant tumours: John Wiley \& Sons; 2011.

18. Gheysarzadeh A, Ansari A, Emami MH, Razavi AE, Mofid MR. Over-expression of low-density lipoprotein receptor-related Protein-1 is associated with poor prognosis and invasion in pancreatic ductal adenocarcinoma. Pancreatology. 2019;19(3):429-35.

19. Kang C, Lee Y, Lee JE. Recent advances in mass spectrometry-based proteomics of gastric cancer. World journal of gastroenterology. 2016;22(37):8283.

20. Lin L-L, Huang H-C, Juan H-F. Discovery of biomarkers for gastric cancer: a proteomics approach. Journal of Proteomics. 2012;75(11):3081-97.

21. Belczacka I, Latosinska A, Metzger J, Marx D, Vlahou A, Mischak H, et al. Proteomics biomarkers for solid tumors: Current status and future prospects. Mass spectrometry reviews. 2019;38(1):49-78.

22. Hou YL, Luo P, Ji Gy, Chen H. Clinical significance of serum IGFBP-3 in colorectal cancer. Journal of Clinical Laboratory Analysis. 2019:e22912.

23. Yoneyama T, Ohtsuki S, Honda K, Kobayashi M, Iwasaki M, Uchida Y, et al. Identification of IGFBP2 and IGFBP3 as compensatory biomarkers for CA19-9 in early-stage pancreatic cancer using a combination of antibody-based and LC-MS/MS-based proteomics. PLoS One. 2016;11(8):e0161009.

24. Hur H, Yu EJ, Ham I-H, Jin H-J, Lee D. Preoperative serum levels of insulin-like growth factor-binding protein 2 predict prognosis of gastric cancer patients. Oncotarget. 2017;8(7):10994.

25. Mortazavi A, Williams BA, McCue K, Schaeffer L, Wold B. Mapping and quantifying mammalian transcriptomes by RNA-Seq. Nature methods. 2008;5(7):621.

26. Hansen KD, Brenner SE, Dudoit S. Biases in Illumina transcriptome sequencing caused by random hexamer priming. Nucleic acids research. 2010;38(12):e131-e.

27. Rajeevan MS, Ranamukhaarachchi DG, Vernon SD, Unger ER. Use of real-time quantitative PCR to validate the results of cDNA array and differential display PCR technologies. Methods. 2001;25(4):443-51.

28. Kim ST, Jang H-L, Lee J, Park SH, Park YS, Lim HY, et al. Clinical significance of IGFBP-3 methylation in patients with early stage gastric cancer. Translational oncology. 2015;8(4):288-94. 
29. Zhang Z-W, Newcomb PV, Moorghen M, Gupta J, Feakins R, Savage P, et al. Insulin-like growth factor binding protein-3: relationship to the development of gastric pre-malignancy and gastric adenocarcinoma (United Kingdom). Cancer Causes \& Control. 2004;15(2):211-8.

30. Yi H, Hwang P, Yang D-H, Kang C-W, Lee D-Y. Expression of the insulin-like growth factors (IGFs) and the IGF-binding proteins (IGFBPs) in human gastric cancer cells. European Journal of Cancer. 2001;37(17):2257-63.

31. Marzec KA, Lin MZ, Martin JL, Baxter RC. Involvement of p53 in insulin-like growth factor binding protein-3 regulation in the breast cancer cell response to DNA damage. Oncotarget. 2015;6(29):26583.

32. Baxter RC. Insulin-like growth factor binding protein-3 (IGFBP-3): Novel ligands mediate unexpected functions. Journal of cell communication and signaling. 2013;7(3):179-89.

33. Schedlich LJ, Le Page SL, Firth SM, Briggs LJ, Jans DA, Baxter RC. Nuclear import of insulin-like growth factor-binding protein-3 and-5 is mediated by the importin $\beta$ subunit. Journal of Biological Chemistry. 2000;275(31):23462-70.

34. Jafari E, Gheysarzadeh A, Mahnam K, Shahmohammadi R, Ansari A, Bakhtyari H, et al. In silico interaction of insulin-like growth factor binding protein 3 with insulin-like growth factor 1 . Research in pharmaceutical sciences. 2018;13(4):332.

35. Xue M, Fang Y, Sun G, Zhuo W, Zhong J, Qian C, et al. IGFBP3, a transcriptional target of homeobox D10, is correlated with the prognosis of gastric cancer. PloS one. 2013;8(12):e81423.

36. Harada A, Jogie-Brahim S, Oh Y. Tobacco specific carcinogen 4-(methyInitrosamino)-1-(3-pyridyl)-1butanone suppresses a newly identified anti-tumor IGFBP-3/IGFBP-3R system in lung cancer cells. Lung Cancer. 2013;80(3):270-7.

37. Han J, Jogie-Brahim S, Harada A, Oh Y. Insulin-like growth factor-binding protein-3 suppresses tumor growth via activation of caspase-dependent apoptosis and cross-talk with NF-KB signaling. Cancer letters. 2011;307(2):200-10.

38. Lee Y-C, Jogie-Brahim S, Lee D-Y, Han J, Harada A, Murphy LJ, et al. Insulin-like growth factor-binding protein-3 (IGFBP-3) blocks the effects of asthma by negatively regulating NF-KB signaling through IGFBP-3R-mediated activation of caspases. Journal of Biological Chemistry. 2011;286(20):17898909.

39. Sano A, Sangai T, Maeda H, Nakamura M, Hasebe T, Ochiai A. Kallikrein 11 expressed in human breast cancer cells releases insulin-like growth factor through degradation of IGFBP-3. International journal of oncology. 2007;30(6):1493-8.

40. Torng P-L, Lee Y-C, Huang C-Y, Ye J, Lin Y-S, Chu Y, et al. Insulin-like growth factor binding protein-3 (IGFBP-3) acts as an invasion-metastasis suppressor in ovarian endometrioid carcinoma. Oncogene. 2008;27(15):2137.

41. Santosh V, Arivazhagan A, Sreekanthreddy P, Srinivasan H, Thota B, Srividya MR, et al. Grade-Specific Expression of Insulin-like Growth Factor-Binding Proteins-2,-3, and-5 in Astrocytomas: IGFBP-3 
Emerges as a Strong Predictor of Survival in Patients with Newly Diagnosed Glioblastoma. Cancer Epidemiology and Prevention Biomarkers. 2010;19(6):1399-408.

42. Adachi Y, Nojima M, Mori M, Kubo T, Yamano Ho, Lin Y, et al. Circulating insulin-like growth factor binding protein-3 and risk of gastrointestinal malignant tumors. Journal of gastroenterology and hepatology. 2019.

43. Gigek CO, Leal MF, Lisboa LCF, Silva PNO, Chen ES, Lima EM, et al. Insulin-like growth factor binding protein-3 gene methylation and protein expression in gastric adenocarcinoma. Growth Hormone \& IGF Research. 2010;20(3):234-8.

44. Shariat SF, Lamb DJ, Kattan MW, Nguyen C, Kim J, Beck J, et al. Association of preoperative plasma levels of insulin-like growth factor I and insulin-like growth factor binding proteins-2 and-3 with prostate cancer invasion, progression, and metastasis. Journal of Clinical Oncology. 2002;20(3):83341.

45. Wang Z, Wang Z, Liang Z, Liu J, Shi W, Bai P, et al. Expression and clinical significance of IGF-1, IGFBP-3, and IGFBP-7 in serum and lung cancer tissues from patients with non-small cell lung cancer. OncoTargets and therapy. 2013;6:1437.

46. Song G, Liu K, Zhu X, Yang X, Shen Y, Wang W, et al. The low IGFBP-3 level is associated with esophageal cancer patients: a meta-analysis. World journal of surgical oncology. 2016;14(1):307.

47. Yan J, Yang X, Li L, Liu P, Wu H, Liu Z, et al. Low expression levels of insulin-like growth factor binding protein-3 are correlated with poor prognosis for patients with hepatocellular carcinoma. Oncology letters. 2017;13(5):3395-402.

\section{Figures}


a

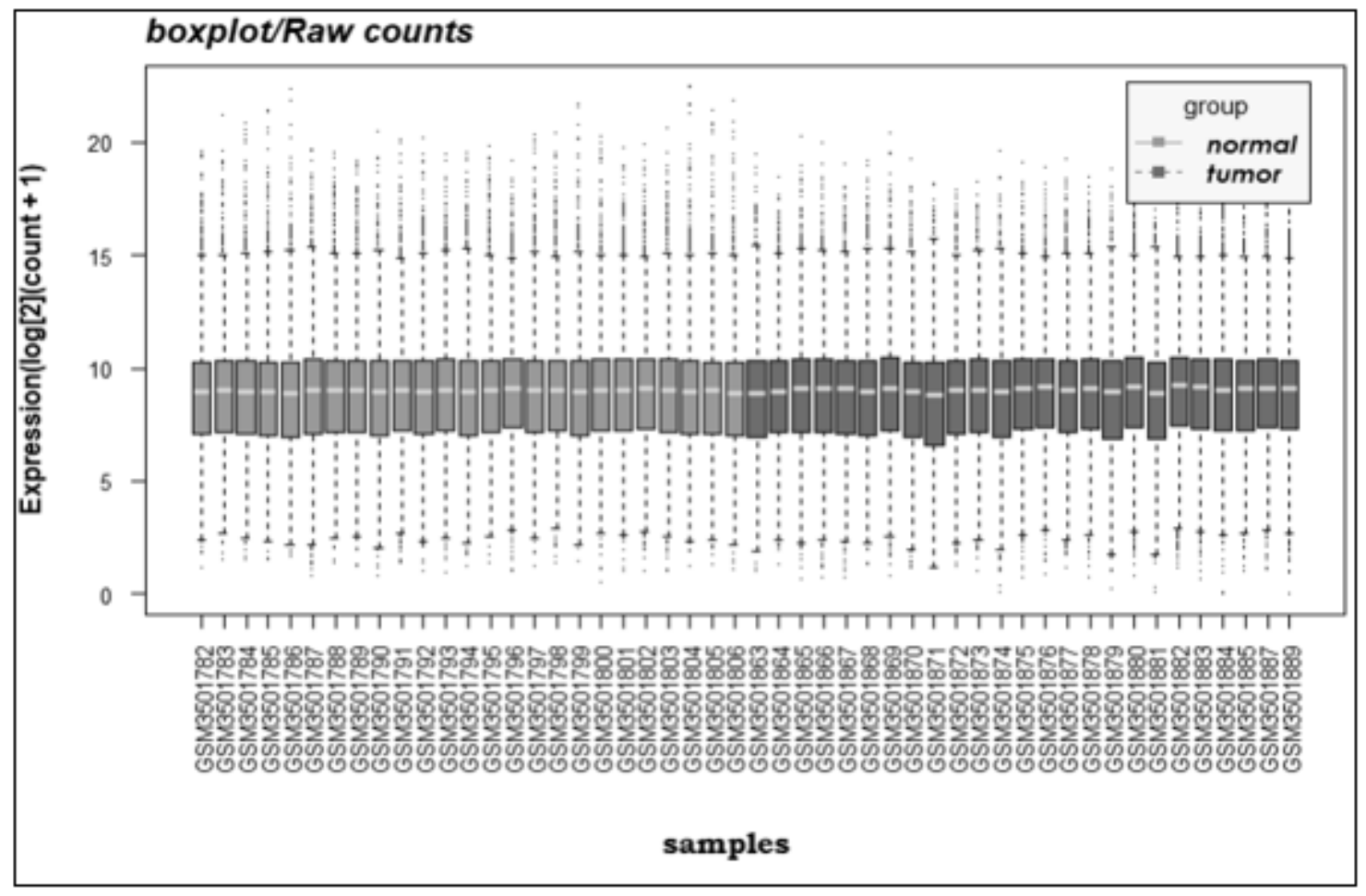

b

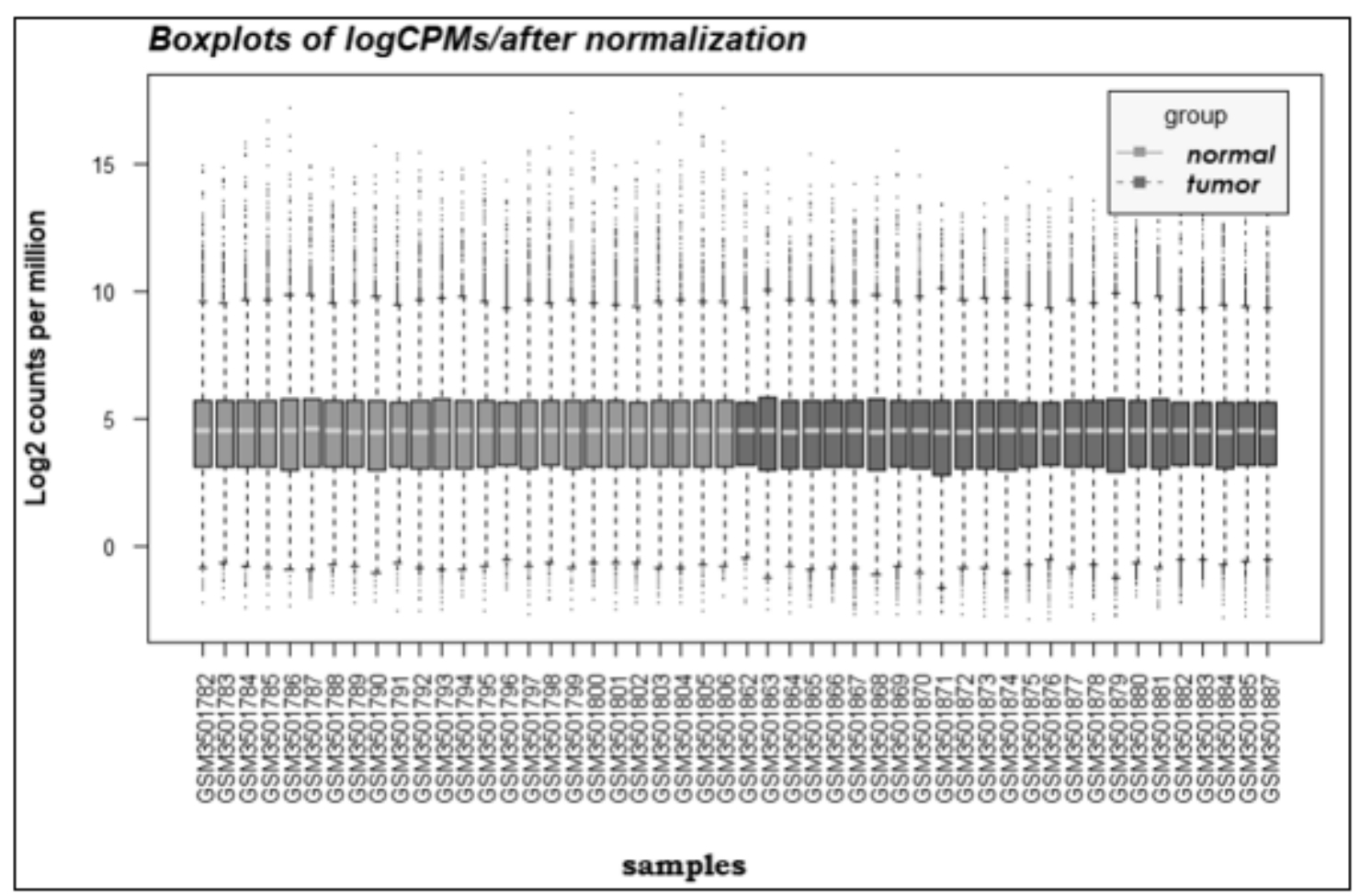

\section{Figure 2}

Distribution of the raw read counts after log2 transformation. a, Box plots of non-normalized count (log2 (counts+1)) per sample (GSE122401). b, Box plots of normalized counts (logCPMs) per sample (GSE122401). 
a

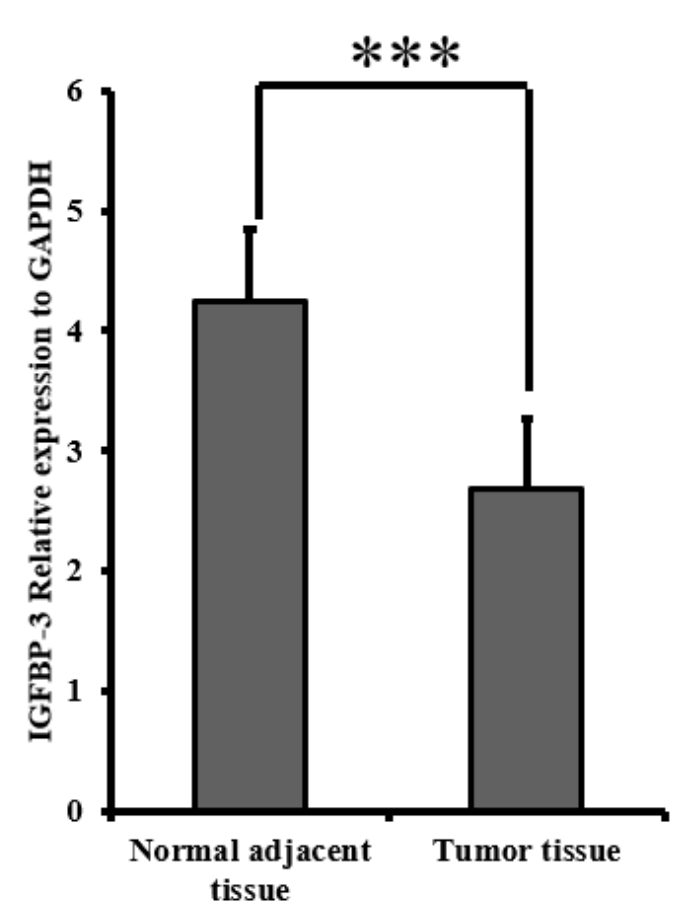

b

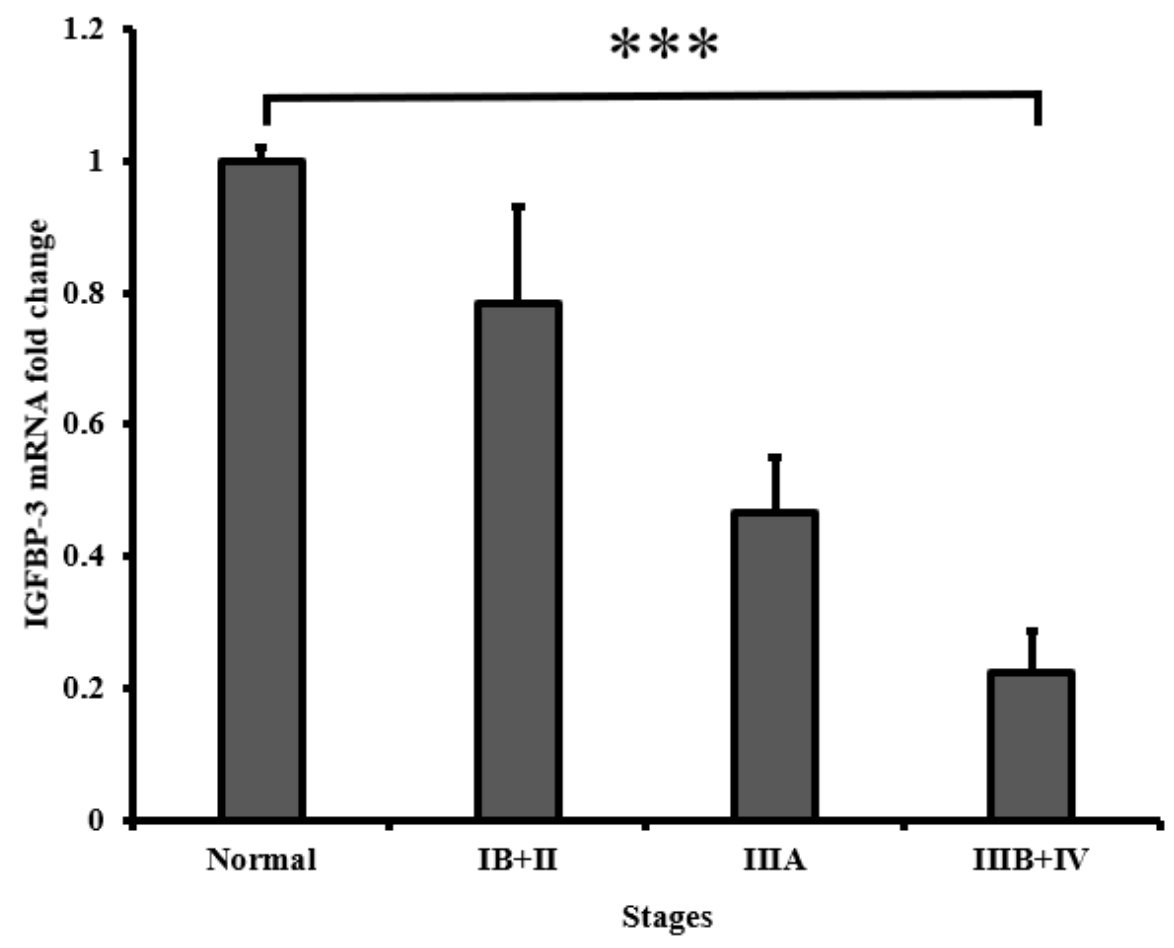

\section{Figure 4}

Down-regulation of the mRNA expression level of IGFBP-3 and TNM stage analysis in gastric cancer.Relative expression was performed with qRT-PCR and calculated with the 2- $\Delta \Delta C$ t method, normalized all curve threshold with using GAPDH as an internal control. a, comparison of relative expression of IGFBP-3 in cancer tissue adjacent non-tumor tissues.b, analyzing of IGFBP-3 fold changes relative expression in gastric cancer stages. Each bar represents for fold change for stages and all stand shown as SEM. ${ }^{\star \star \star}$ represented as $\mathrm{P}<0.001$ is significant vs. control group. 
a

$\frac{16 \mathrm{IB}}{T} \frac{17 \mathrm{IB}}{\mathrm{T} N \mathrm{~N}} \frac{18 \mathrm{IV}}{\mathrm{T} N \mathrm{~N}} \frac{19 \mathrm{IIIA}}{\mathrm{T} N \mathrm{~N}} \frac{20 \mathrm{IIIB}}{\mathrm{T} N \mathrm{~N}}$

IGFBP-3

$32(\mathrm{kD})$

$\beta$-Actin $45(\mathrm{kD})$

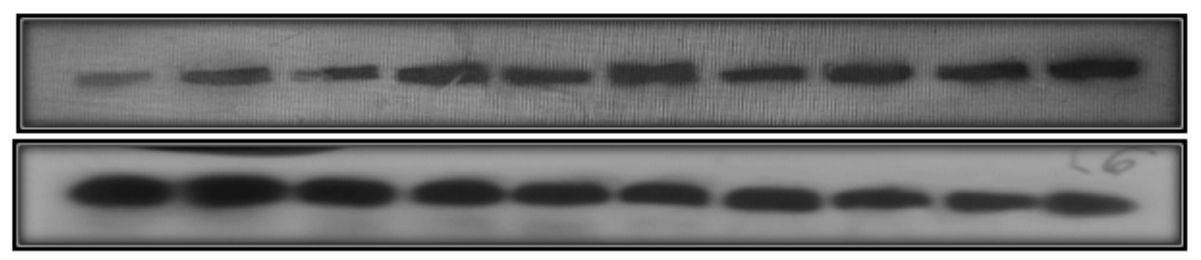

b

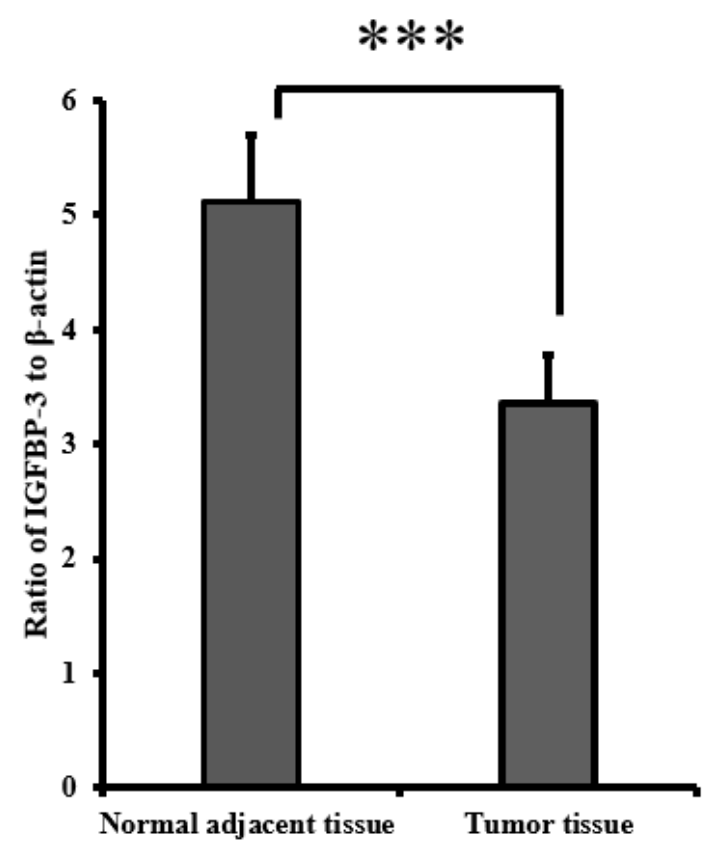

$* * *$

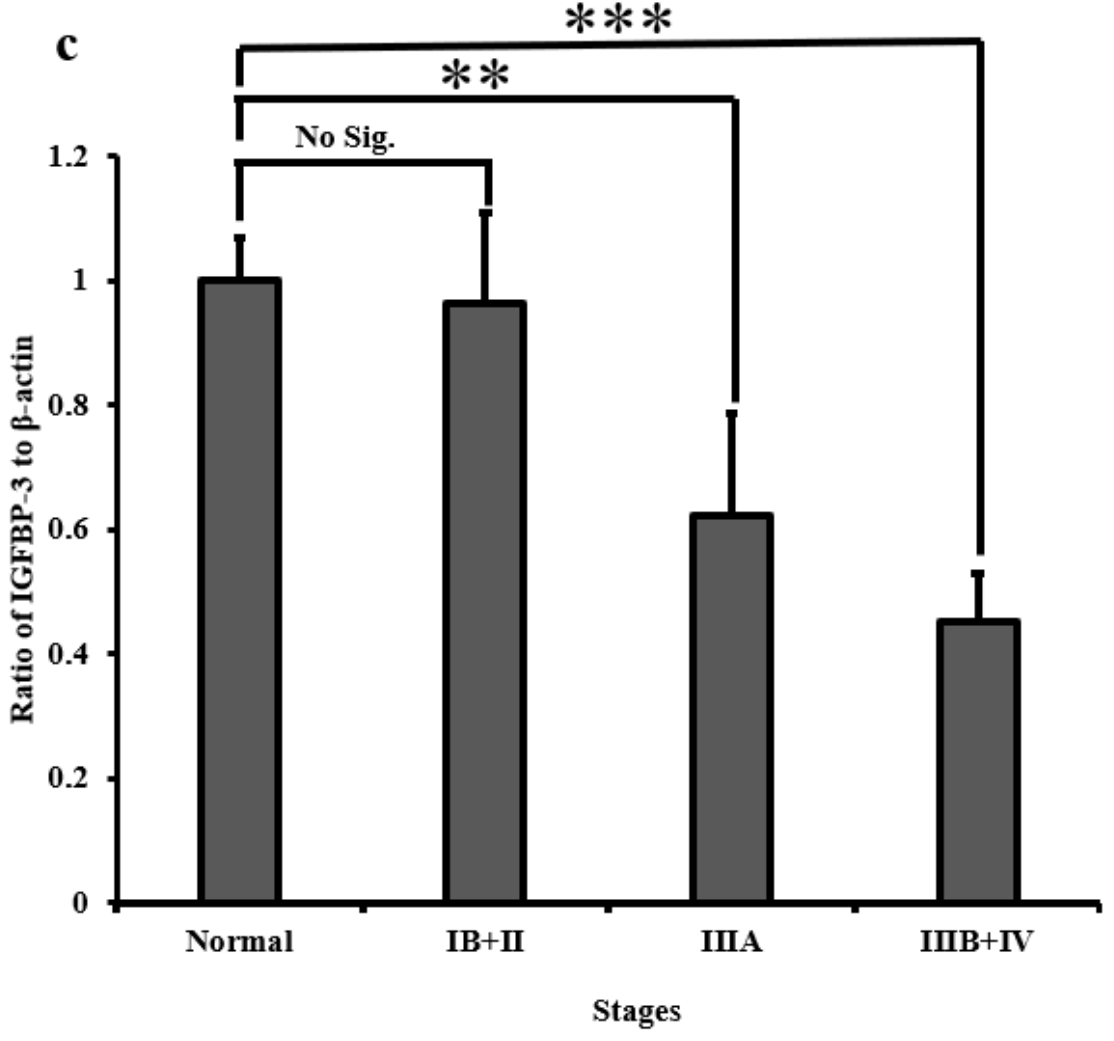

Figure 6

Protein expression of IGFBP-3 determined with western blotting. All bands normalized with $\beta$-actin as internal control, the intensity of all bands calculated with Image $\mathrm{J}$ software. $\mathrm{a}$, a representative image of IGFBP-3 bands in tumoral cancer $(\mathrm{T})$ and normal $(\mathrm{N})$ tissue. $b$, ratio protein expression in gastric cancer tissue in comparison with normal tissue. $c$, analyzing of protein fold change according to TNM stage classification. All stand are shown as SEM, $* \star(P<0.01)$ and $* \star \star ~(P<0.001)$ is significant vs. control group. No Sig means not significant 
a

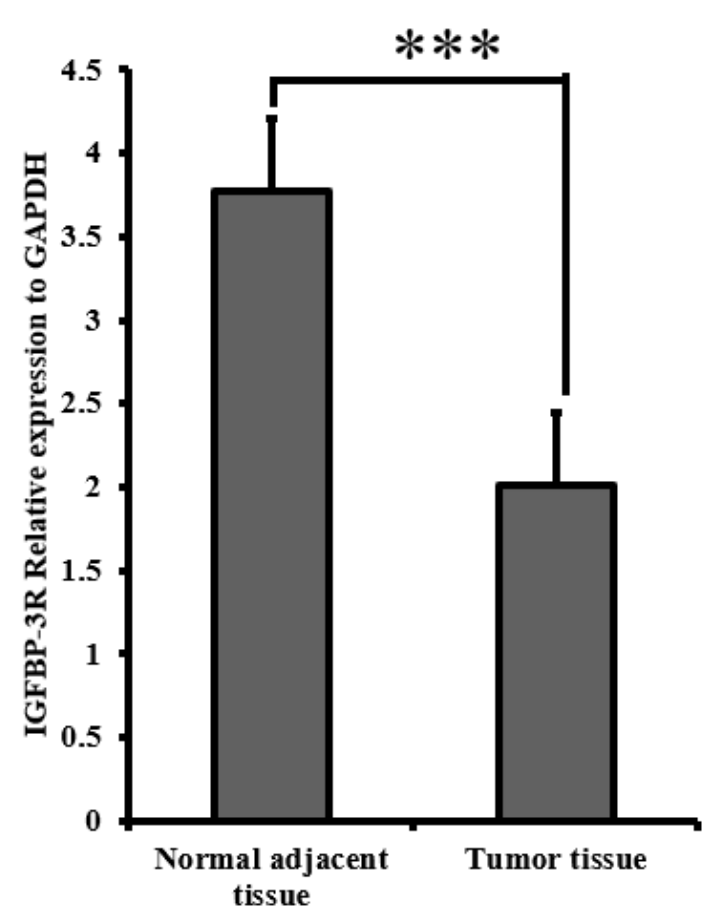

b

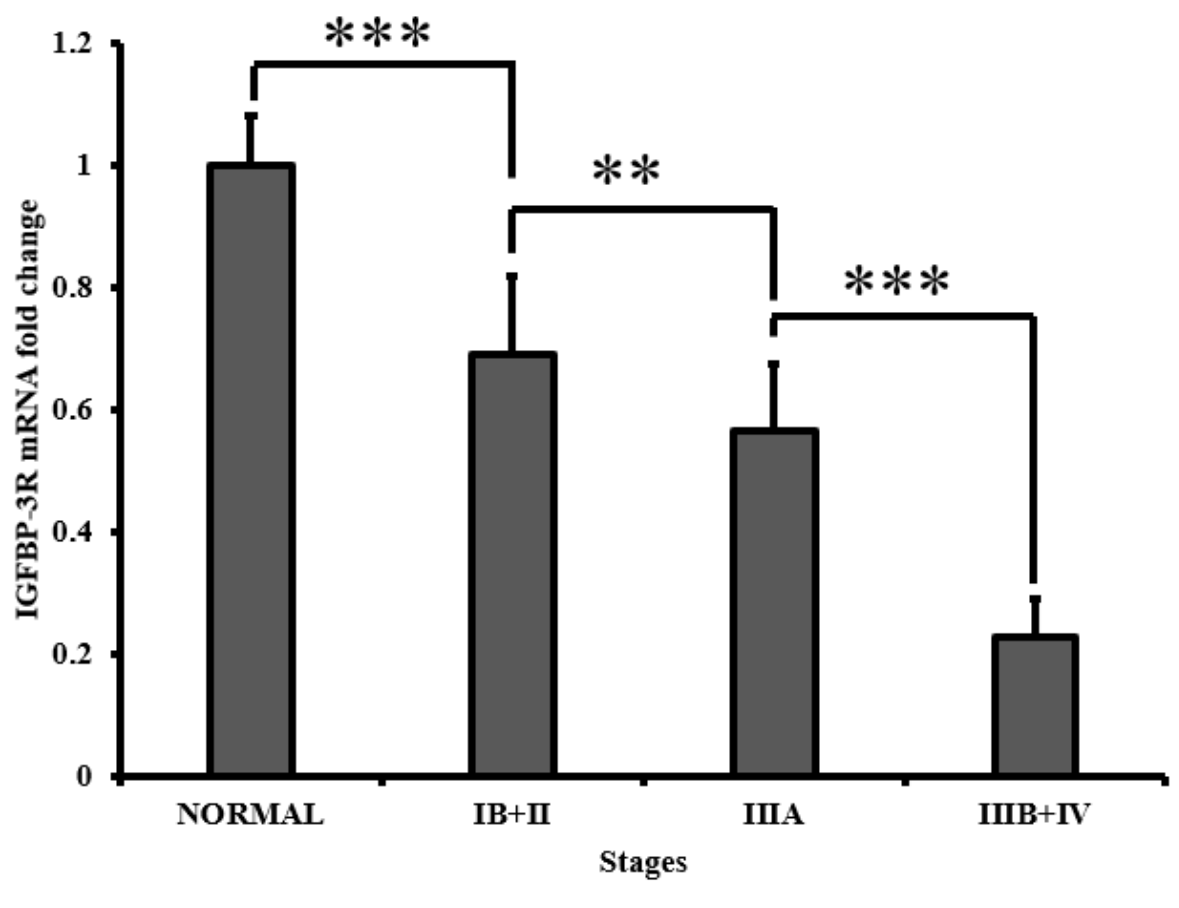

Figure 8

Analyzing of IGFBP-3R mRNA expression fold change in gastric cancer. a,Comparison of IGFBP-3R relative expression gastric cancer tissue in comparison with normal adjacent tissue. $b$, analyzing of IGFBP-3R mRNA fold change according to stages. All stands are shown as SEM, $* *(P<0.01)$ and $* \star \star(P$ $<0.001$ ) is significant according to the previous stage. 
a

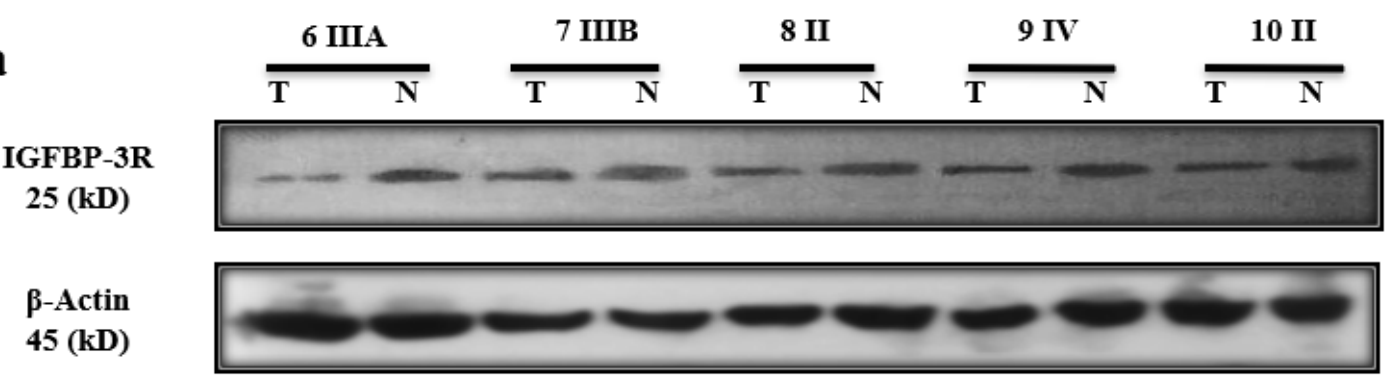

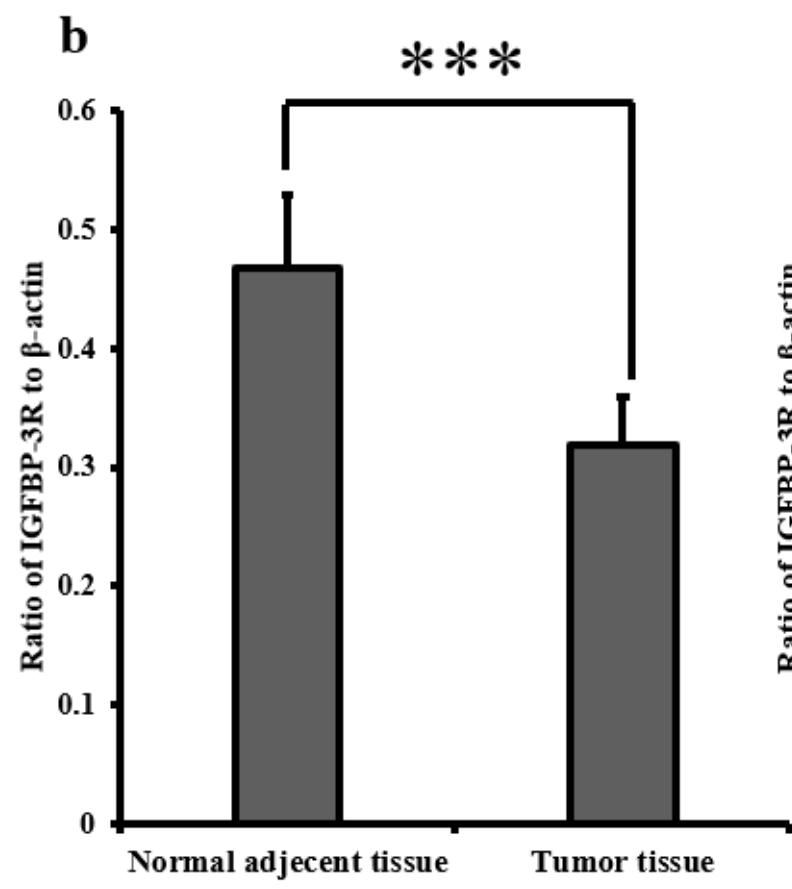

Tumor tissue

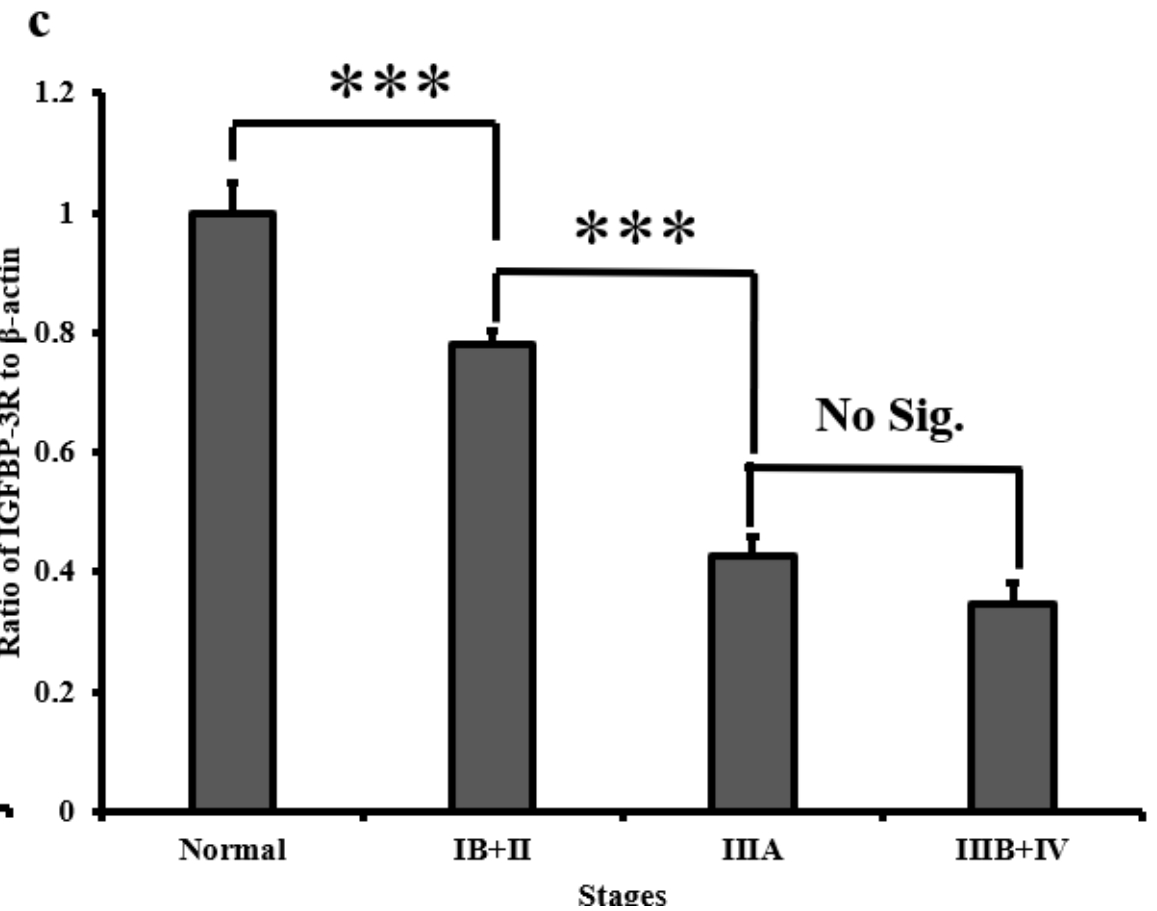

Figure 9

Analyzing of IGFBP-3R protein expression in gastric cancer and stages by using western blotting. All bands normalized with $\beta$-actin. a, representative bands in the tumor ( $T$ ) and normal (N) tissue. b, IGFBP3R protein expression reduced in all patient samples. c, analysis of IGFBP-3R pattern according to TNM stage classification. Each bar represented as fold change, all stands are shown as SEM, *** $(P<0.001)$ is significant vs. the previous stage and No Sig means not significant. 

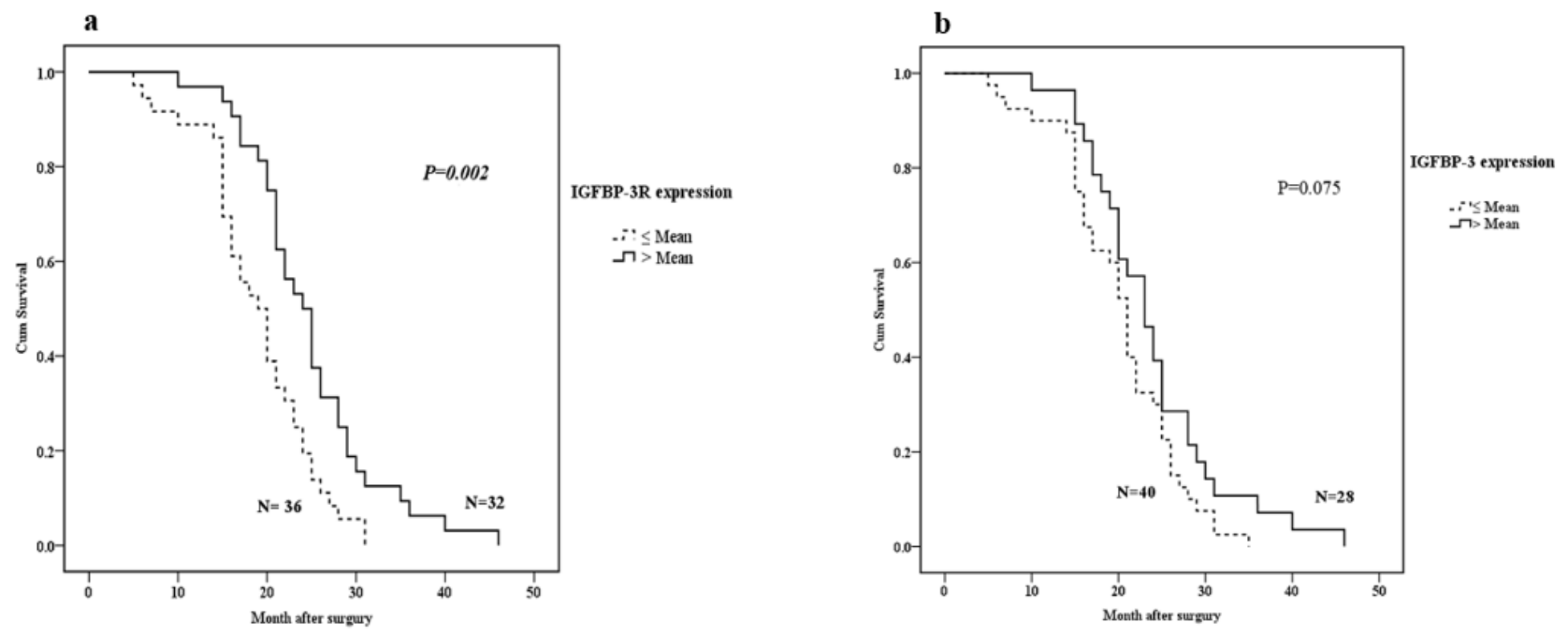

Figure 11

Correlation of IGFBP-3 and IGFBP-3R expression with cumulative survival patient for 68 gastric cancer patient. Favored or non-favored patient with different expression (low and high expression based on mean) was calculated and analysis with the log-rank test. a, Low or high level of IGFBP-3R expression correlates with a poorer overall ( $P=0.002$, log-rank test). $b$, relative expression of IGFBP-3 has no significant correlation with overall survival of a patient with gastric cancer. 